\title{
Effect of biomass-based carbon capture on the sustainability and economics of pulp and paper production in the Nordic mills
}

\author{
Katja Kuparinen $^{1}$ (D) Satu Lipiäinen ${ }^{1}$ (D) $\cdot$ Esa Vakkilainen $^{1}$ (D) $\cdot$ Timo Laukkanen $^{2}$ (D)
}

Received: 20 May 2021 / Accepted: 18 December 2021 / Published online: 4 January 2022

(c) The Author(s) 2021

\begin{abstract}
Bioenergy with carbon capture and storage (BECCS) is one of the key negative emission technologies (NETs). Large-scale implementation of BECCS has been criticized of the associated increase in land use. The existing large Nordic pulp and paper production units enable BECCS deployment without additional land use, as they currently release large amounts of bio-based carbon dioxide $\left(\mathrm{CO}_{2}\right)$. The application of BECCS in pulp mills has been found technically feasible in earlier studies. This study explores key factors that affect the propensity to invest in BECCS in different types of existing European pulp and paper mills. The results give fresh understanding on the effects of BECCS on the market price of pulp and paper products and the required level of incentives. Based on statistical data, the marginal carbon dioxide credit $\left(€\right.$ per ton $\mathrm{CO}_{2}$ ) to make BECCS profitable was derived. The results show that the required level of credit greatly depends on the mill type and details and that the feasibility of BECCS does not clearly correlate with the economic performance or the measured efficiency of the mill. The most promising mill type, a market kraft pulp mill, would find BECCS profitable with a credit in the range of $62-70 € / \mathrm{t}_{\mathrm{CO} 2}$ and a credit of $80 € / \mathrm{t}_{\mathrm{CO} 2}$ would decrease pulp production costs by $15 € / \mathrm{t}_{\text {product }}$ on average if $50 \%$ of $\mathrm{CO}_{2}$ emissions was captured. The EU Emission Trading System (ETS) is the main policy instrument to achieve the climate targets related to fossil energy use, but does not yet contemplate bio-based emissions.
\end{abstract}

Keywords Bioenergy with carbon capture and storage BECCS · Pulp mill · Climate change mitigation $\cdot$ Negative $\mathrm{CO}_{2}$ emissions $\cdot$ Emission trade

$\begin{array}{ll}\text { Abbreviations } \\ \text { a } & \text { Year } \\ \text { BECCS } & \text { Bioenergy with carbon capture and storage } \\ \mathrm{CCS} & \text { Carbon capture and storage } \\ \mathrm{CO}_{2} & \text { Carbon dioxide }\end{array}$

Katja Kuparinen

katja.kuparinen@lut.fi

1 Lappeenranta-Lahti University of Technology LUT, Yliopistonkatu 34, Lappeenranta, Finland

2 Aalto University, Otakaari 4, Espoo, Finland 


$\begin{array}{ll}\text { ETS } & \text { Emission Trading System } \\ \text { EU } & \text { European Union } \\ \text { HFO } & \text { Heavy fuel oil } \\ \text { LWC } & \text { Lightweight coated } \\ \text { MEA } & \text { Monoethanolamine } \\ \text { NET } & \text { Negative emission technologies } \\ \text { NG } & \text { Natural gas } \\ \text { SC } & \text { Supercalendered } \\ \text { SEC } & \text { Specific energy consumption }\end{array}$

\section{Introduction}

The pulp and paper industry is one of the largest industrial energy users and the largest industrial bioenergy user (IEA, 2019). Most of the pulp produced is chemical (kraft) pulp. In kraft pulping, about half of the wood raw material is used for the end product, while the remaining part is used to generate renewable energy. One of the largest sections of biomass boilers in the world are recovery boilers, producing bioenergy as part of the pulping process (Vakkilainen et al., 2013). In most mills, a separate biomass boiler combusts bark and other wood residue for additional energy generation. This produces a notable amount of biogenic carbon dioxide $\left(\mathrm{CO}_{2}\right)$ that currently is released to the atmosphere.

The European strategic long-term vision for a prosperous, modern, competitive, and climate-neutral economy (European Commission, 2018) aims at net-zero greenhouse gas emissions. A sustainable energy system has a key role in reaching the target, since in the European Union (EU) area $75 \%$ of greenhouse gases originate from energy supply. The European Green Deal set the target for climate neutrality by 2050 (European Commission, 2019a). The EU Emission Trading System (ETS) is the main policy instrument to achieve the climate targets relating to fossil energy use (Moya \& Pavel, 2018). The EU ETS is a cap-and-trade system that puts a price on $\mathrm{CO}_{2}$ emissions by creating an annually reduced amount of allowances for permissible emissions.

An average European kraft pulp mill emits over $0.5 \mathrm{Mt}$ of biogenic $\mathrm{CO}_{2}$ per year (Jönsson \& Berntsson, 2012), which makes them large point sources of $\mathrm{CO}_{2}$. The global technical carbon capture potential from kraft pulp mills has been estimated at approximately $137 \mathrm{Mt}_{\mathrm{CO} 2} / \mathrm{a}$ (Kuparinen et al., 2019). Therefore, kraft pulp mills offer a significant potential for implementation of bioenergy with carbon capture and storage (BECCS). While the power and heat sector followed by oil and gas, iron and steel, and cement industries have a high potential for $\mathrm{CO}_{2}$ emissions reduction in the Nordic countries, the pulp and paper sector accounts for majority of biogenic emissions and enables zero or negative emissions (Onarheim, Mathisen, et al., 2015; Teir et al., 2010). BECCS is considered as one of the key negative emission technologies (NETs), but large-scale BECCS often raises a concern over increasing land use, since it is seen as promoting additional use of biomass to energy. A high level of technological knowhow and existing large point sources of bio-based $\mathrm{CO}_{2}$ are important prerequisites for BECCS implementation (Hansson et al., 2020). Thus, the deployment of BECCS in the existing processes of the large pulp and paper production units in the Nordic Countries can be seen as an attractive possibility, without a need for additional biomass harvesting.

The pulp and paper industry is a diverse industrial sector with high energy intensity and a large share of bioenergy. Largest part of fossil-based $\mathrm{CO}_{2}$ emission savings from the pulp and paper industry can be expected to come from replacing the current use of fossil fuels 
with renewables (Moya \& Pavel, 2018) for which several feasible options exist (Kuparinen \& Vakkilainen, 2017). The relatively low share of fossil fuels compared with many other industries urges the pulp and paper industry to look for other emission reduction options in addition to fossil fuel replacement. Continuing technology improvement and commissioning of new mills with the state-of-the-art technologies improve both resource and energy efficiency and explain, along with old unit closures, the improvement of energy efficiency and the subsequent reduction in emissions (Kähkönen et al., 2019). In kraft pulp mills, fossil $\mathrm{CO}_{2}$ emissions are often small enough to make the mill a carbon sink even with a low carbon capture rate (Kuparinen et al., 2019). Pulp and paper processes produce secondary steam and low-temperature heat streams of which in many cases only a part is utilized in the processes. Process integration offers possibility to improve efficiency by utilizing these streams. This appears as an additional incentive for BECCS integration to pulp and paper processes. Rewarding captured bio- $\mathrm{CO}_{2}$ is not yet contemplated in the EU ETS (Moya \& Pavel, 2018) nor in the European Green Deal (European Commission, 2019a). Lack of political prioritization and, consequently, the lack of policy incentives are currently considered the main barriers preventing investments in BECCS (Fridahl \& Lehtveer, 2018).

Capture of biogenic carbon dioxide from the outgoing flows from pulping is still a little studied subject (Leeson et al., 2017), but recent studies have found the application of BECCS in pulp mills technically feasible (IEAGHG, 2016; Kuparinen et al., 2019). Previous studies in this area have mainly focused on modeling of carbon capture integration in kraft pulp mill operation (Kuparinen et al., 2019; Onarheim et al., 2017a), estimation of costs (Fuss et al., 2018; IEAGHG, 2016; Karjunen et al., 2017; Onarheim et al., 2017b) or the possible scale or emission reduction potential (Leeson et al., 2017; Fuss et al., 2018; Kuparinen et al., 2019, IEA, 2020). The most studied capture method is the commercial monoethanolamine (MEA) post-combustion process (Karjunen et al., 2017; Leeson et al., 2017; Onarheim et al., 2017a). Based on earlier estimates, the cost of $\mathrm{CO}_{2}$ avoided in pulp mills ranges between 20 and $92 €$ per ton of $\mathrm{CO}_{2}$ depending on the chosen processes and mill details (Fuss et al., 2018; IEAGHG, 2016). Onarheim et al. (2017b) estimated that a negative emissions credit of 60-80 $€$ per ton of $\mathrm{CO}_{2}$ would be needed for carbon capture and storage (CCS) implementation to be profitable in a kraft pulp mill, the costs being lower for a stand-alone mill and higher for an integrated mill.

The aim of this paper is to find out when BECCS can be economically applied in existing pulp and paper industry, namely when is the revenue from generated $\mathrm{CO}_{2}$ per ton of product higher than the cost of applying BECCS in different types of mills. The study is based on mill-level energy consumption and $\mathrm{CO}_{2}$ emissions data, $\mathrm{CCS}$ calculations for the studied mills, and cost evaluation. It is thus far unknown but interesting to see which product areas would first see BECCS profitable from the various products and differing processes of the pulp and paper industry.

Even though improved energy efficiency in general leads to the decrease in $\mathrm{CO}_{2}$ emissions, an energy-efficient mill is not necessarily $\mathrm{CO}_{2}$-efficient due to different products, process alternatives and mill configurations. Stenqvist and Åhman (2016) also noticed that in a heterogeneous sector like the pulp and paper industry, benchmark-based allowance allocation of the EU ETS does not result in the best performance due to concentrating on specific energy consumption (SEC) instead of emission intensity. Therefore, this study also estimates the $\mathrm{CO}_{2}$ intensity of different types of mills. Even though the biogenic carbon dioxide generation from kraft pulping covers the largest part of emissions, the economic lifeline for the pulp and paper industry is producing paper and board.

The results of this paper advance the knowledge on the effects of BECCS implementation in different types of pulp and paper mills and on what combination of cost factors and 
mill operational features encourages investments in BECCS, also considering the effect of the ETS price. As the previous studies in the area mainly focus on the possibilities of BECCS in kraft pulp mills or the sector in general, this study gives new knowledge and fresh understanding on the potential for investing in NETs in the existing mills that have differing energy procurement schemes and produce various types of products. The utilization of mill-level data from existing, different types of pulp and paper mills is a novel approach to estimating the feasibility of BECCS in the pulp and paper sector. The implementation of BECCS is more dependent on the lack of incentives and political support than on the technological readiness level of the processes, and hence, it is essential to advance the knowledge on the prerequisites of feasible concepts.

\section{Methods and material}

To evaluate the mill-level effects of carbon capture and to define the prerequisites for economical implementation of BECCS, mill-level data were analyzed and the effects of CCS were calculated, followed by cost estimation and careful analysis of the results. Figure 1 presents the methodology of the study.

\subsection{BECCS implementation in the pulp and paper industry units}

The implementation of BECCS affects the mill operations. $\mathrm{CO}_{2}$ can be captured from combustion processes using several methods including pre-combustion, post-combustion, and oxy-combustion technologies. These methods can be applied to pulp and paper mills. Many of the methods are still in the development stage, and their utilization in pulp and paper industry is limitedly studied (Kuparinen et al., 2019; Leeson et al., 2017). For this study, the MEA process was chosen for the reference method. The capture rate of the MEA process is typically at $80-90 \%$, and as a post-combustion process, it can be easily applied to existing mills. The MEA process uses electricity and steam, which affects the energy balance of the mill (Onarheim et al., 2017a). The heat use for solvent regeneration used in this study for the MEA process is $3.7 \mathrm{MJ} / \mathrm{kg}_{\mathrm{CO} 2}$ (Onarheim, Garðarsdòttir, et al., 2015).

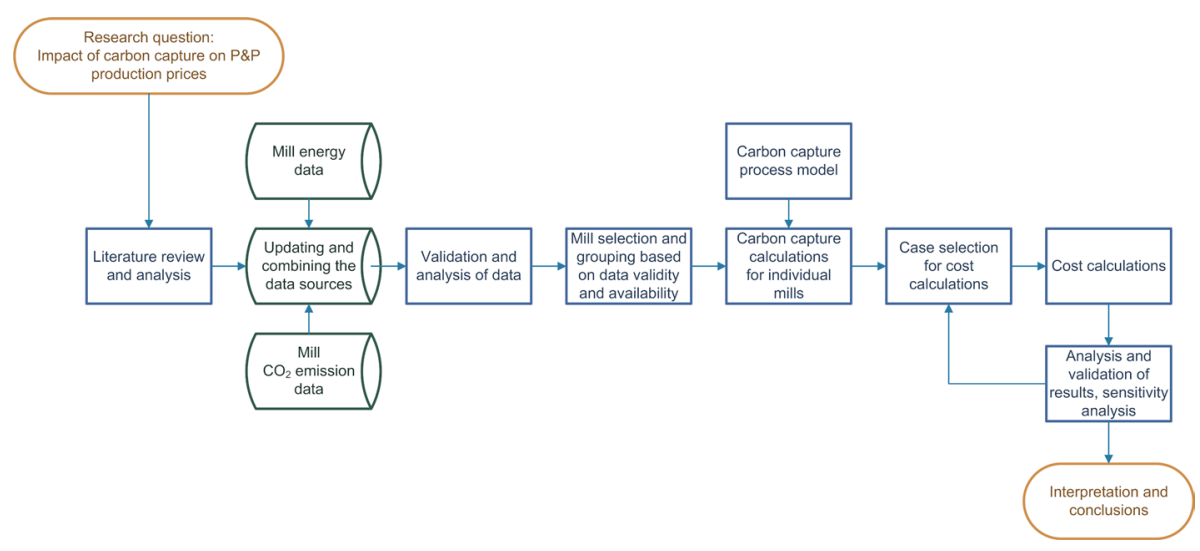

Fig. 1 Research methodology flowchart 
BECCS can be implemented in several processes in a pulp mill. The largest point sources of $\mathrm{CO}_{2}$ are the combustion processes; in a kraft pulp mill, the recovery boiler, the lime kiln, and in almost all Nordic mills, the biomass boiler. These are mainly sources of biogenic $\mathrm{CO}_{2}$, apart from the lime kiln, where $\mathrm{CO}_{2}$ originates from both wood raw material and the used fuel, which in many mills still is fossil. Typically, a modern kraft pulp mill is energy-independent and even produces additional electricity and steam (Vakkilainen \& Kivistö, 2014). In an integrated pulp and paper mill, paper or board production follows the pulping process. Paper production is typically both steam- and electricity-consuming process, and therefore, adding new processes such as CCS is seen to need additional energy generation in the case of integrated mills (IEAGHG, 2016; Kuparinen et al., 2019). In paper production, most of the energy is consumed in paper drying.

\subsection{Data on energy balances and $\mathrm{CO}_{2}$ emissions}

Energy consumption and its allocation to products (pulp, paper, or board) in different types of pulp and paper industry units was studied earlier to estimate the energy efficiency of the Finnish forest industry mills (Kähkönen et al., 2019). Within the present study, the statistical data collected earlier were updated using the most recent references (Finnish Forest Industries Federation, 2020; IRENA, 2018) and combined with $\mathrm{CO}_{2}$ emission statistics (Energy Authority of Finland, 2019). The data were then used to further analyze the emission intensity of products and its impact on the feasibility of carbon capture.

Statistical data typically include sources of uncertainties. In this case, the uncertainties mainly relate to the energy consumption and production values, which are not necessarily collected according to the same principles in different mills (Kähkönen et al., 2019). Most of the data are both company and unit specific, which makes it in some cases difficult to estimate which operations are included in the data. It is also typical that several companies operate in the same mill site, e.g., chemicals production or biomass boiler can be a part of the pulp mill or a separate company. An on-site located energy company can produce energy for the pulp mill, but also for the surrounding community, and therefore, the allocation of the emissions and fuel use is challenging. The effect of these uncertainties was minimized during the study by using careful consideration and the choice of studied mills (European Commission, 2019b). This consideration included not only choosing the mills with available energy and $\mathrm{CO}_{2}$ data, but also evaluation of the accuracy and comparability of the data.

In statistical representation of pulp and paper fossil $\mathrm{CO}_{2}$ emissions, separate boilers are only included if they clearly are part of the mill process. Boilers that do produce significant amounts of energy for external use are considered part of the energy business and not part of the pulp and paper industry. Similar division was used in this study.

\subsection{The selected mills and categories}

Energy balances of pulp and paper mills (Kähkönen et al., 2019) were used to derive the marginal $\mathrm{CO}_{2}$ cost $\left(€ / \mathrm{t}_{\mathrm{CO} 2}\right)$ for various mill types producing pulp and paper. The studied mill types were market kraft pulp mill, supercalendered/lightweight coated (SC/LWC) paper mill, fine paper integrate, newsprint mill, and testliner mill. The chosen mill types represent the majority of mills in the Nordic countries. To make the analysis viable for the whole Nordics, for each category mills that can be grouped into good, average, and low performers economically based on industrial experience were chosen. The mills had 
therefore widely differing energy economics, i.e., electricity and heat consumption per same product varied. The performance categories imply overall performance considering, e.g., technical age and economic performance and are not associated with, e.g., fossil fuel usage. In addition, the effect of the choice of the main fossil fuel was evaluated, i.e., oil or natural gas (NG).

Table 1 shows the selected categories and introduces the studied mills within the categories. Two to five mills were included in the categories. The studied mills were chosen based on both data availability and their suitability to fit in the categories. Many mills produce more than one product. The mills were grouped based on their primary product to form a consistent view on the subject. Mills operating on the same site were considered integrated even when operated by separate companies, because they often have at least partly common energy infrastructure, and in some cases, are also reported in statistics as one unit.

Energy efficiency can be defined as the ability to produce high amount of product using a small amount of energy. Energy efficiency does not necessarily correlate with the economic performance of the mill, even though improved energy efficiency is likely to decrease production costs. The following specific energy figures were defined for the mills in each category to analyze the key factors affecting the propensity to invest in BECCS:

- electricity consumption and production $\left(\mathrm{MWh}_{\mathrm{e}} / \mathrm{t}_{\text {product }}\right)$

- heat consumption and production $\left(\mathrm{MWh}_{\mathrm{th}} / \mathrm{t}_{\text {product }}\right)$

- excess/purchased electricity $\left(\mathrm{MWh}_{\mathrm{e}} / \mathrm{t}_{\text {product }}\right)$ and heat $\left(\mathrm{MWh}_{\mathrm{th}} / \mathrm{t}_{\text {product }}\right)$

- fossil fuel use $\left(\mathrm{MWh}_{\text {fuel }} / \mathrm{t}_{\text {product }}\right)$

- fossil $\mathrm{CO}_{2}$ production $\left(\mathrm{t}_{\mathrm{CO} 2} / \mathrm{t}_{\text {product }}\right)$

- biogenic $\mathrm{CO}_{2}$ production $\left(\mathrm{t}_{\mathrm{CO} 2} / \mathrm{t}_{\text {product }}\right)$

Table 1 Mill classification. HFO stands for heavy fuel oil, NG for natural gas, and Bio for biofuels

\begin{tabular}{lllll}
\hline Group & Mill & Performance & Integration level & Fossil fuel $^{a}$ \\
\hline Market Kraft Pulp Mill & M1 & Good & Yes & Bio \\
& M2 & Average & No & HFO \\
& M3 & Average & No & HFO \\
& M4 & Average & No & Bio/NG \\
& M5 & Low & No & NG \\
SC/LWC Paper Mill & S1 & Good & Yes & NG \\
& S2 & Average & Yes & HFO \\
\multirow{5}{*}{ Fine Paper Integrate } & S3 & Low & Yes & NG \\
& F1 & Good & Yes & HFO \\
& F2 & Average & Yes & NG \\
Testliner Mill & F3 & Low & Yes & HFO \\
& T1 & Good & Yes & NG \\
& T2 & Average & Yes & HFO \\
& T3 & Average & Yes & HFO \\
Newsprint Mill & T4 & Low & Yes & HFO \\
& N1 & Good & Yes & HFO \\
& N2 & Low & Yes & HFO \\
\hline
\end{tabular}

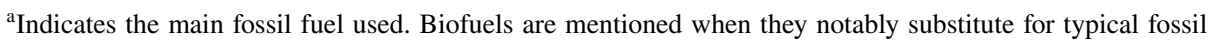
fuel use 
The mills present different ways of energy procurement. The fossil fuels given in Table 1 indicate the main fossil fuel used, but some mills also use smaller amounts of other fossil fuels, such as coal or peat. Biofuel use and bio-based $\mathrm{CO}_{2}$ emissions were calculated from the use of various types of biofuels, including black liquor, bark and other mill side streams. In the case of integrated mills, the specific energy figures and emissions were calculated for pulp and paper/board combined despite the final use of pulp; in integrated mills, all or part of the produced pulp is usually further used in the paper or board production. Heat and electricity consumptions were calculated using factors to divide the electricity and heat consumption for products to detect a comparable value for each product type and mill. The energy efficiency and allocation of energy consumption to the products as well as emission intensity were calculated from the collected data based on the principles presented earlier (Fleiter et al., 2012; Kähkönen et al., 2019). Default $\mathrm{CO}_{2}$ emission factors and lower heating values for the fossil and bio-based fuels were used based on references (Alakangas et al., 2016; Fleiter et al., 2012; Statistics Finland, 2020). Fossil $\mathrm{CO}_{2}$ emissions were assumed to come from the named fuel only, even though a wide variety of small amounts of other fossil fuels have often been used, e.g., propane, peat, coal, and petroleum coke.

Figure 2 presents the specific energy consumption and production figures for each mill to give a view on their energy efficiency. The figures show that all market kraft pulp mills are energy-independent in both power and heat, and commonly produce both in excess of their own needs. Among the other groups, electricity purchase is often needed, and heat production is typically adjusted by additional production to satisfy the mill's requirement. The figure shows some differences between the performance categories; for example, in SC/LWC paper mill and fine paper mill groups specific heat consumption is the highest for the low-performance mills and the lowest for the high-performance mills. However, there is no clear pattern between the categories in all mill groups, which could be expected as the categories are not based solely on SEC or amount of excess energy, but overall performance including economic performance. Excess electricity and heat are additional sources of income for some Nordic mills, as they sell them to the surrounding community. Considering fossil fuel use, clear differences between the groups cannot be detected, even though the average consumption is higher in the groups of SC/LWC paper mills and newsprint mills. The fossil fuel consumption of some individual mills differs greatly from the average.

Figure 3 presents the specific fossil and biogenic $\mathrm{CO}_{2}$ emissions $\left(\mathrm{kg}_{\mathrm{co} 2} / \mathrm{t}_{\text {product }}\right)$ for the studied mills. Mill M1 uses only a minor amount of fossil fuels, and therefore, the amount of fossil emissions is not visible in the figure. The $\mathrm{CO}_{2}$ intensity of fuel oil is higher than that of natural gas, which can be seen when comparing Figs. 3a and 2c; the mills using natural gas produce relatively less $\mathrm{CO}_{2}$ emissions compared with the oil users.

The specific $\mathrm{CO}_{2}$ emission values show that there are clear differences between individual mills, but they do not seem to correlate with the economic performance of the mills. Most fossil $\mathrm{CO}_{2}$ per ton of product is produced in the SC/LWC paper mills and the fine paper mills. The share of fossil $\mathrm{CO}_{2}$ emissions is small in many mills, especially in the market kraft pulp mills and the testliner mills, where the average carbon capture rates required for carbon-neutral production are 3.1 and $4.8 \%$, respectively. In fine paper mills, the average share of fossil $\mathrm{CO}_{2}$ emissions is $15.5 \%$. The highest fossil emission shares are in the groups of SC/LWC paper mills and newsprint mills, 36 and 31\%, respectively. Since the group of newsprint mills only consists of two mills, any conclusions should be viewed with caution. 


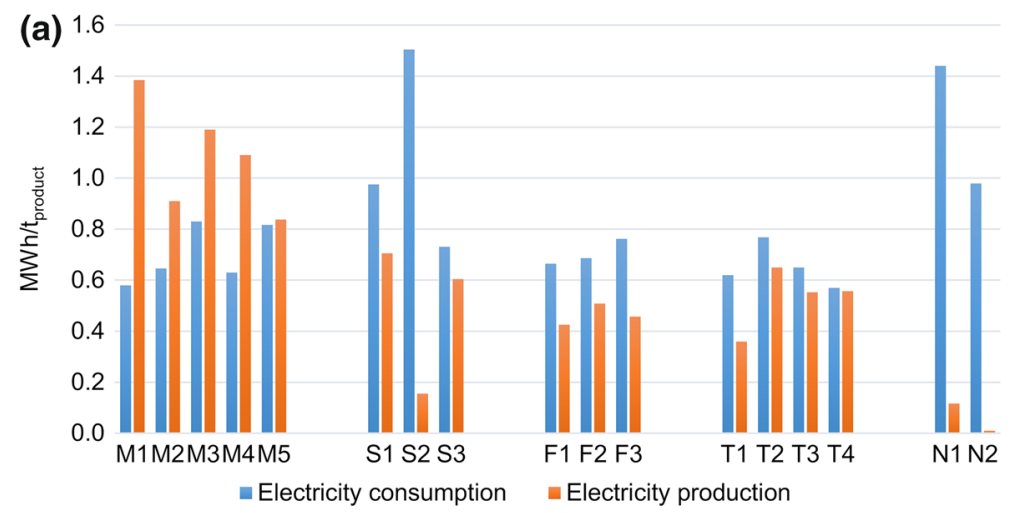

(b) 8.0

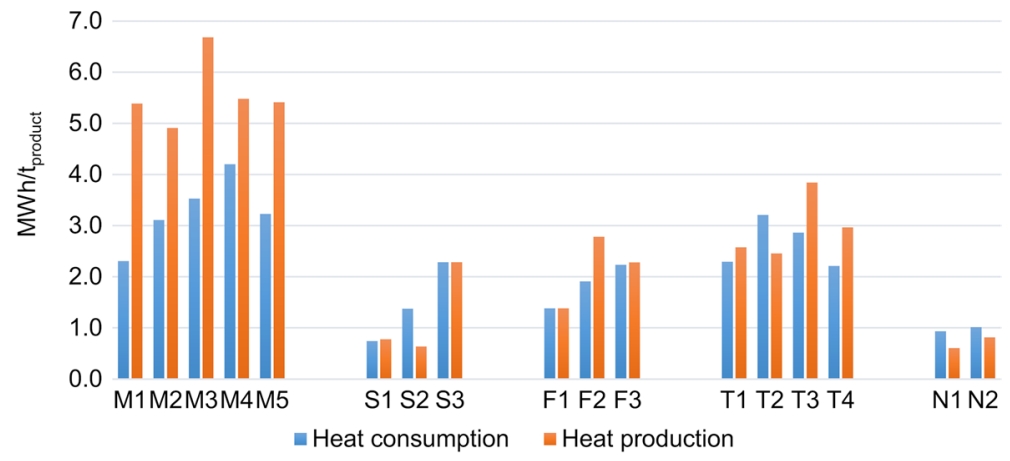

(c) 1.4

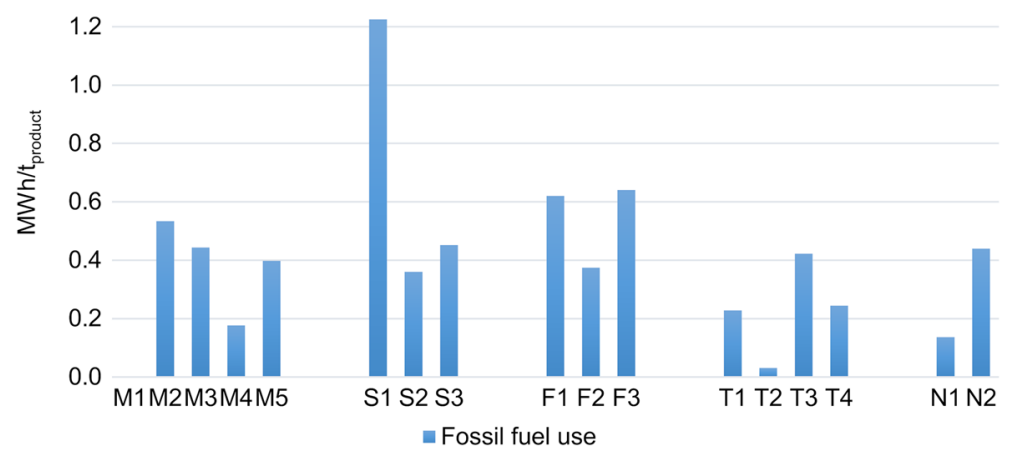

Fig. 2 Specific energy balance figures for the studied mills: electricity consumption and production $\left(\mathrm{MWh}_{\mathrm{e}} /\right.$ $\left.\mathrm{t}_{\text {product }}\right) \mathbf{a}$, heat consumption and production $\left(\mathrm{MWh}_{\mathrm{th}} / \mathrm{t}_{\text {product }}\right) \mathbf{b}$, fossil fuel use $\left(\mathrm{MWh} / \mathrm{t}_{\text {product }}\right) \mathbf{c}$, and excess electricity and heat production $\mathbf{d}$ 
(d) 3.5

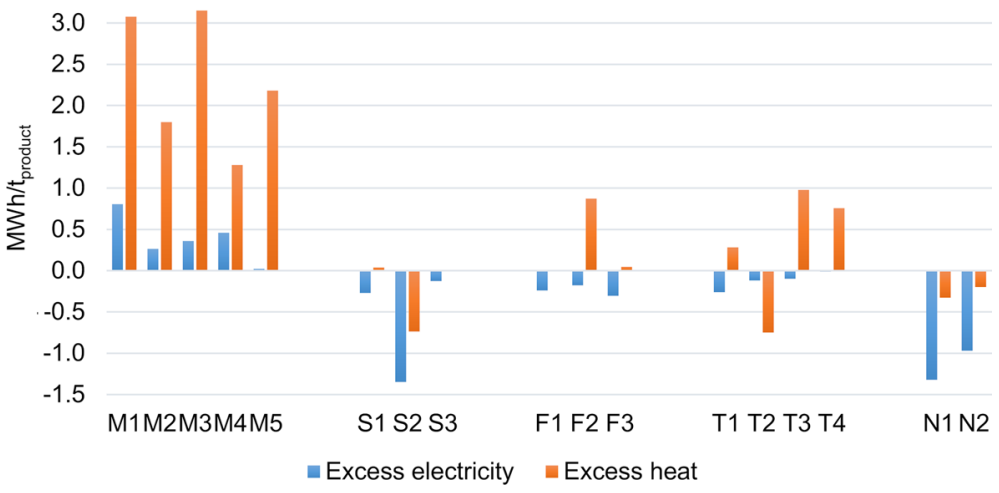

Fig. 2 (continued)

(a)

Fossil $\mathrm{CO}_{2}\left[\mathrm{~kg}_{\mathrm{CO} 2} / \mathrm{t}_{\text {product }}\right]$

350

300

250

200

150

100

50

0

S1 S2 S3

F1 F2 F3

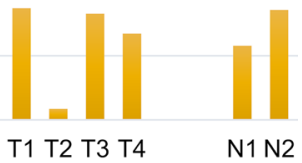

(b)

Bio- $\mathrm{CO}_{2}\left[\mathrm{~kg}_{\left.\mathrm{CO}_{2} / \mathrm{t}_{\text {product }}\right]}\right]$

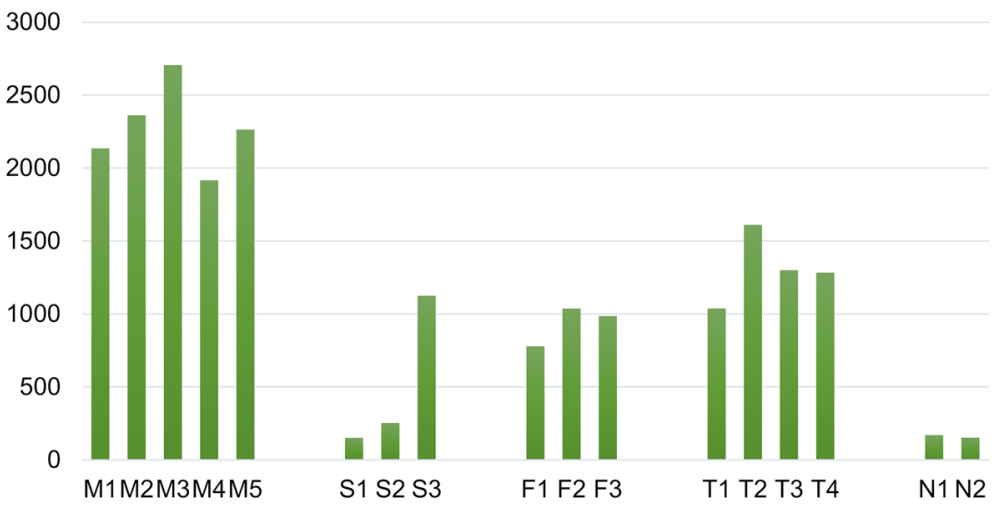

Fig. 3 Specific $\mathrm{CO}_{2}$ emissions of the studied mills: fossil emissions $\mathbf{a}$ and biogenic emissions $\mathbf{b}$ 


\subsection{Basis for the cost calculations}

The costs of generated $\mathrm{CO}_{2}$ per ton of product were calculated based on the assumptions and mill values presented earlier. The aim was to estimate the effect of ETS price $\left(€ / t_{\mathrm{CO} 2}\right)$ on the production costs and when the revenue from generated $\mathrm{CO}_{2}$ is higher than the cost of applying BECCS. The following factors were assumed to affect the production costs of pulp and paper along with BECCS application:

- ETS price/level of emission allowances

- carbon capture cost

- possible compensation for negative emissions

- electricity and heat for the capture process

- mill economic performance (good/average/low)

- main fossil fuel choice (oil/natural gas)

Several cases were studied to estimate the effect of ETS price and BECCS implementation in different types of mills. The cases were compared to a base case, where the needed emission allowances are allocated with no cost, and no carbon capture is applied. Table 2 presents the studied cases. Capture rate represents the amount of captured $\mathrm{CO}_{2}$ from the mill total emissions, including both fossil and biogenic $\mathrm{CO}_{2}$. Cases $\mathrm{A}, \mathrm{B}$, and $\mathrm{C}$ estimate the effect of ETS price increase on the production costs. Cases B1, B2, and B3 were used to calculate the required compensation for negative emissions to cover the costs of CCS in the mills that reach negative emissions with the chosen carbon capture rates. Fixed negative emission compensation was used to calculate the production price change in Cases B1, $\mathrm{B} 2$, and B3. The effect of fossil fuel choice and changes in fossil fuel prices was estimated for Cases A, B, and C by evaluating the change in production costs if the mills used natural gas or oil.

Based on the literature, the cost of carbon capture from the flue gases of pulp and paper mill combustion processes or biomass combustion varies in the range of 40-92 $€$ / $\mathrm{t}_{\mathrm{CO} 2}$ (IEAGHG, 2016; Karjunen et al., 2017; Leeson et al., 2017; IEA, 2020; Kearns et al., 2021). In this study, an estimation of $62 € / t_{\mathrm{CO} 2}$ was used in all cases, including energy costs and assuming a MEA-based process and capture from one source of flue gas. Capture cost greatly depends on the process details, such as $\mathrm{CO}_{2}$ concentration, the choice of capture process, process integration level, energy costs, and economy of scale. Garðarsdóttir et al. (2018) stated that the economy of scale and energy costs are significant factors in carbon capture costs, the costs of steam being the largest factor, especially in large-scale capture processes. As Fig. 2 shows, some mills have abundant excess heat while others

Table 2 Studied cases

\begin{tabular}{llll}
\hline Case & $\begin{array}{l}\text { ETS price }[€ / \\
\left.\mathrm{t}_{\mathrm{CO} 2}\right]\end{array}$ & $\begin{array}{l}\text { Negative emission com- } \\
\text { pensation }\left[€ / \mathrm{t}_{\mathrm{CO} 2}\right]\end{array}$ & $\begin{array}{l}\text { Carbon } \\
\text { capture } \\
\text { rate }\end{array}$ \\
\hline Case A & 25 & - & - \\
Case B & 50 & - & - \\
Case B1 & 50 & 30 & $10 \%$ \\
Case B2 & 50 & 80 & $20 \%$ \\
Case B3 & 50 & 80 & $50 \%$ \\
Case C & 75 & - & - \\
\hline
\end{tabular}


are covering the process heat demand by purchase. This sets the studied mills in different positions regarding applying new processes, as does the fact that the temperature and pressure levels of the usable heat and steam flows differ from mill to mill, thus affecting their suitability for utilization. The statistical approach of this study does not allow going into mill-specific details in the available steam and heat flows.

A mill typically has several $\mathrm{CO}_{2}$ flows, and it is likely not economical to apply the capture process to all the possible flows, but rather to consider the largest one(s). In a mill producing kraft pulp, the largest one is often the recovery boiler. The economy of scale leads to lower specific capital cost for a larger facility compared with a smaller one, and both the flow size and $\mathrm{CO}_{2}$ concentration affect the costs. Defining the feasible capture scale requires mill-specific consideration and taking into account mill location, transportation options, and $\mathrm{CO}_{2}$ storage or utilization possibilities. The transport and storage possibilities account for a significant part of total costs (Garðarsdóttir et al., 2018), and therefore, the local conditions greatly affect the attractiveness of applying the process and the scale of it. Careful consideration is needed to estimate the effects of the scale-dependent factors in a real investment case. The magnitude of the pulp mill processes means that the relatively low capture rate of $20 \%$ of the total emissions leads to an average annual capture exceeding $300 \mathrm{kt}_{\mathrm{CO} 2}$ in the groups with highest $\mathrm{CO}_{2}$ emissions, namely the market kraft pulp mill and testliner mill groups. For the fine paper integrate group, the respective value is $282 \mathrm{kt}_{\mathrm{CO} 2} / \mathrm{a}$, for the $\mathrm{SC} / \mathrm{LWC}$ mill group $134 \mathrm{kt}_{\mathrm{CO} 2} / \mathrm{a}$, and for the newsprint mill group $53 \mathrm{kt}_{\mathrm{CO} 2} / \mathrm{a}$.

\section{Results}

The results aim at finding out what combinations of ETS price or price for negative $\mathrm{CO}_{2}$, fossil fuel price, energy efficiency, and mill economic competitiveness will promote investments in BECCS, and what is the impact of increased ETS to the market price of pulp and paper products. The results also highlight how the situation varies between the mill type and performance.

\subsection{Effect of increased ETS price}

ETS price for the total amount of produced fossil $\mathrm{CO}_{2}$ notably impacts the production costs of pulp and paper products compared with the case where emission allowances are given with no cost. Figure 4 shows the increase in the production price when ETS price for fossil $\mathrm{CO}_{2}$ emissions is set at 25,50 , and $75 € / \mathrm{t}_{\mathrm{CO} 2}$. Both pulp and paper are considered products in these calculations, despite their possible further on-site use in integrated mills. The production cost increase shown in Fig. 4 is thus lower for the integrated mills than it would be if the cost increase was only allocated to the pulp or paper.

The increase in the ETS price has the largest effect on the production costs in SC/LWC paper mills and fine paper integrates, which could be expected due to their higher specific fossil $\mathrm{CO}_{2}$ emissions (Fig. 3). A moderate ETS price, $25 € / t_{\mathrm{CO} 2}$, raises the production costs less than $5 € / t_{\text {product }}$ in most mills. When the ETS price increases to $50 € / t_{\mathrm{CO} 2}$, the production cost increase still stays below $5 € / t_{\text {product }}$ on average in market kraft pulp mills and testliner mills, while the SC/LWC paper mills and fine paper mills face an average increase of about $9 € / \mathrm{t}_{\text {product }}$. When the ETS price is set at $75 € / \mathrm{tCO}_{2}$, Mill S1 has the highest production cost increase, $24 € / t_{\text {product }}$, while the average in the market kraft pulp mills group is at 6 $€ / t_{\text {product }}$ and in testliner mill group at $5 € / t_{\text {product }}$. 


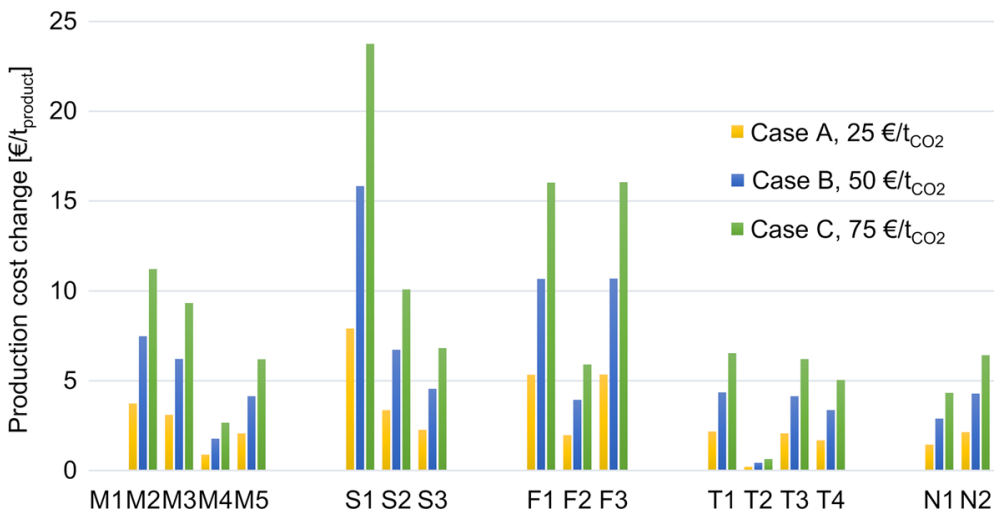

Fig.4 Increase in production costs in the selected mills when the ETS price is $25 € / t_{\mathrm{CO} 2}(\mathrm{Case} A), 50 € / t_{\mathrm{CO} 2}$ (Case $\mathrm{B})$, or $75 € / \mathrm{t}_{\mathrm{CO} 2}($ Case $\mathrm{C})$

\subsection{Effect of negative $\mathrm{CO}_{2}$ compensation}

Carbon capture processes are known to be technically feasible when integrated with pulp and paper production. Their economic feasibility requires income that covers the costs from the investment and operation. When fossil $\mathrm{CO}_{2}$ is captured, a mill operator benefits if CCS deployment decreases the need to buy emission allowances. Similarly, compensation for negative emissions could be a way to promote BECCS. Figure 5 shows the change in production costs per ton of product in Cases B1, B2, and B3 with fixed compensation (30 and $80 € / \mathrm{t}_{\mathrm{CO} 2}$ ) for negative emissions.

Low capture rates and relatively low compensation for negative emissions leads to production cost increases in Case B1. In this case, the production costs increase on average approximately $10 € / t_{\text {product }}$ in the market kraft pulp mill, SC/LWC paper mill, and fine paper integrate groups, while in the testliner mill group the increase is $6 € / t_{\text {product }}$ and in the newsprint mill group $4 € / t_{\text {product }}$. Case $\mathrm{B} 2$, where negative emission compensation is higher, differs from B1, especially in the market kraft pulp mill and testliner mill groups, where the average production cost changes are -2 and $0 € / t_{\text {product }}$, respectively. In Case B3 with a high negative emission compensation and higher capture rate than in $\mathrm{B} 2$, the production costs decrease on average 14 and $7 € / t_{\text {product }}$ in the market kraft pulp mill and testliner mill groups, respectively. The other mill groups do not make profit in Case B3: production costs increase on average by $7 € / t_{\text {product }}$ in SC/LWC mill group, by $4 € / t_{\text {product }}$ in fine paper integrate group, and by $4 € / \mathrm{t}_{\text {product }}$ in newsprint mill group.

The results highlight the importance of mill-specific consideration: For example, Mill S1 has a high share of fossil $\mathrm{CO}_{2}$ emissions (68\% of total emissions) and does not benefit from negative emission compensation in any of the calculated cases. Therefore, a higher $\mathrm{CO}_{2}$ capture rate raises the production cost in Mill S1, as the estimated capture costs exceed the savings from ETS. Therefore, Mill S1 would benefit from higher ETS price, whereas Mill M1 as a representative of the other extreme needs compensation for negative emissions or profit in some other form from biogenic $\mathrm{CO}_{2}$ to be able to economically apply CCS.

The calculated production cost changes can be compared with recent market price of pulp to estimate their significance. At the beginning of the year 2021, the market price of wood pulp was around $800 € / \mathrm{t}$ in Europe (IndexMundi, 2021). The average 


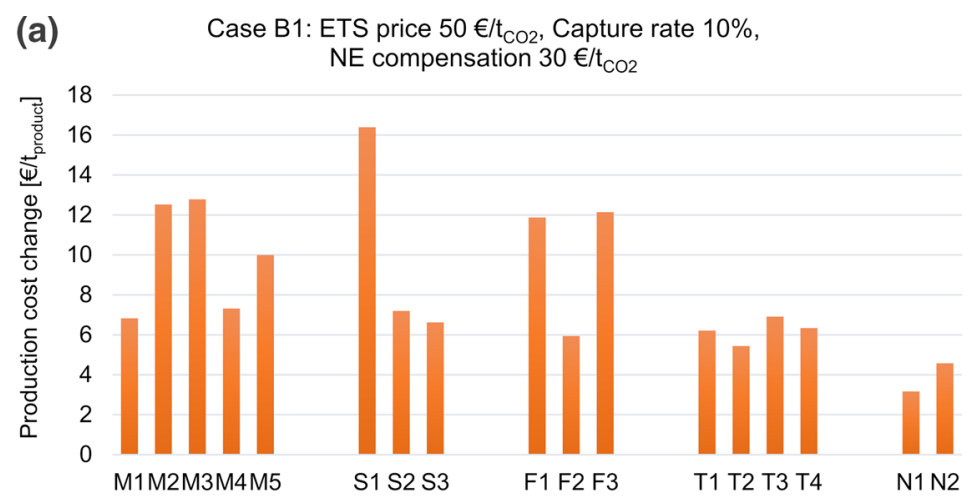

(b) Case B2: ETS price $50 € / \mathrm{t}_{\mathrm{CO} 2}$, Capture rate $20 \%$, $\mathrm{NE}$ compensation $80 € / \mathrm{t}_{\mathrm{CO} 2}$

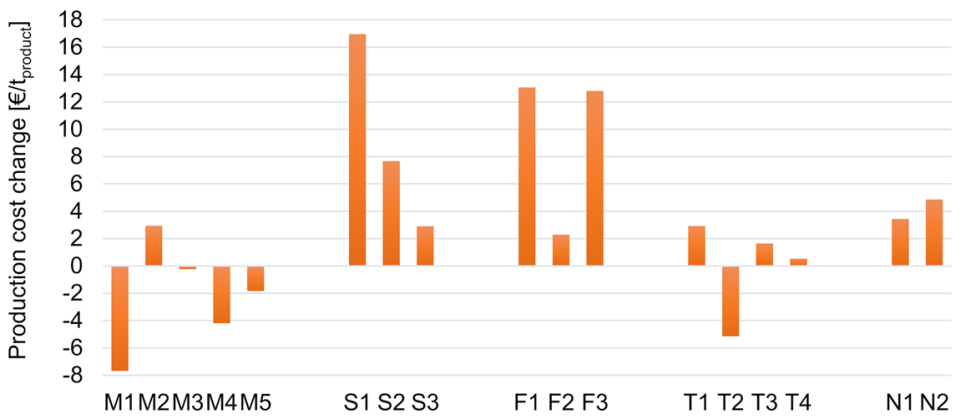

(c) Case B3: ETS price $50 € / \mathrm{t}_{\mathrm{CO} 2}$, Capture rate $50 \%$,

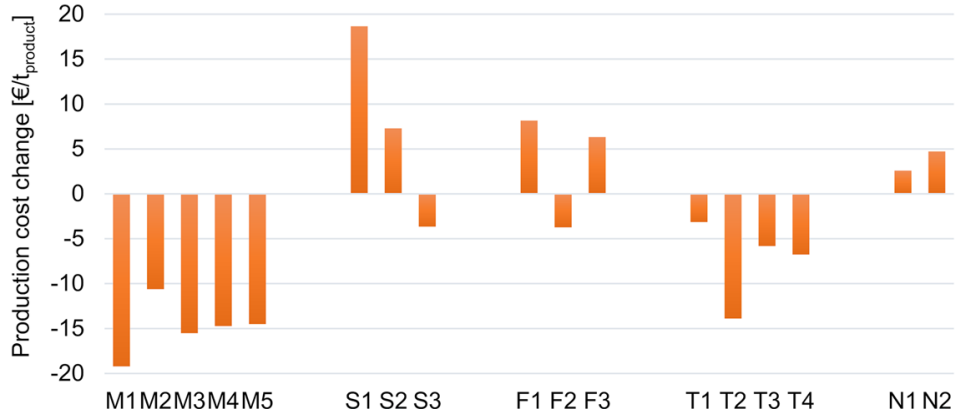

Fig. 5 Changes in production prices $\left(€ / \mathrm{t}_{\text {product }}\right)$ in Cases B1 $\mathbf{a}, \mathrm{B} 2 \mathbf{b}$, and B3 $\mathbf{c}$, when the negative emission (NE) compensation is fixed at 30 and $80 € / t_{\mathrm{CO} 2}$

production cost changes calculated for the market kraft pulp mill group are thus $1.2 \%$ of pulp price in Case B1, $-0.3 \%$ in Case B2, and $-1.9 \%$ in Case B3.

Marginal compensation ( $€ / t_{\mathrm{CO} 2}$ ) for negative $\mathrm{CO}_{2}$ emissions was calculated to show how much compensation would be needed to cover the costs of carbon capture in the studied mills. Figure 6 shows the results for the mills that reach negative emissions with the chosen 
(a) Case B1: ETS price $50 € / \mathrm{t}_{\mathrm{CO} 2}$, Capture rate $10 \%$

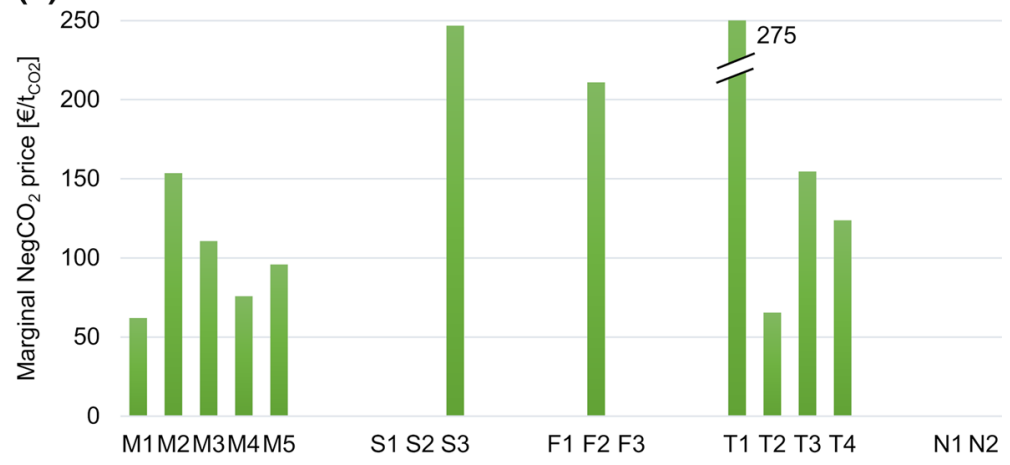

(b) Case B2: ETS price $50 € / \mathrm{t}_{\mathrm{CO} 2}$, Capture rate $20 \%$

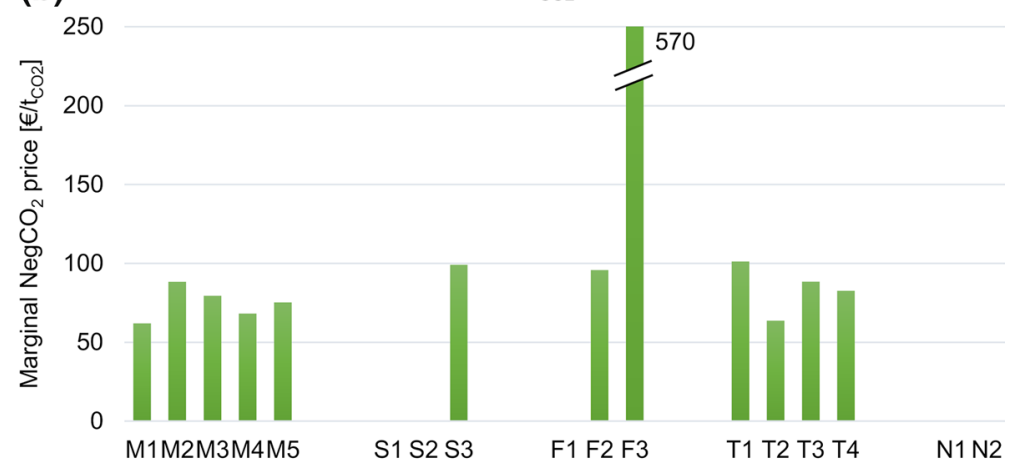

(c) Case B3: ETS price $50 € / \mathrm{t}_{\mathrm{CO} 2}$, Capture rate $50 \%$

250

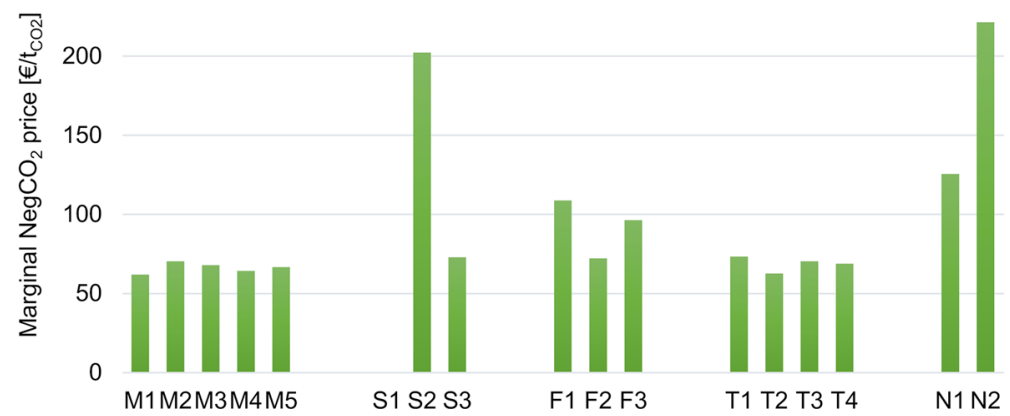

Fig. 6 Required marginal compensation for negative emissions $\left(€ / \mathrm{t}_{\mathrm{CO} 2}\right)$ to cover the costs of CCS in Cases $\mathrm{B} 1 \mathbf{a}, \mathrm{B} 2 \mathbf{b}$, and $\mathrm{B} 3 \mathbf{c}$. The marginal compensation is shown only for the mills, which reach negative $\mathrm{CO}_{2}$ emissions with the given capture rate

capture rates in the Cases $\mathrm{B} 1, \mathrm{~B} 2$, and $\mathrm{B} 3$. The calculated marginal negative $\mathrm{CO}_{2}$ price represents a break-even price using the given assumptions.

Based on the calculations, market kraft pulp mills have the highest potential for BECCS implementation, followed by testliner mills, i.e., these groups are able to apply the carbon 
capture process with the lowest negative emission compensation. However, the marginal compensation for negative emissions is high; for market kraft pulp mills, it is 100, 75, and $66 € / \mathrm{t}_{\mathrm{CO} 2}$ on average in Cases $\mathrm{B} 1, \mathrm{~B} 2$, and $\mathrm{B} 3$, respectively. The lowest value can be found for the least $\mathrm{CO}_{2}$-intensive mill, M1. Similarly, the values for testliner mills are 155, 84 , and $69 € / \mathrm{t}_{\mathrm{CO} 2}$ on average. It is important to notice that a clear pattern cannot be seen between the performance categories. The economic performance nor energy efficiency of the mills does not seem to have an impact on the feasibility of BECCS implementation. The attractiveness of carbon capture depends more on the mill type, although notable variation also inside the mill groups can be seen. It can thus be concluded that BECCS is a new dimension, which does not clearly correlate with the performance, technical age, nor the measured efficiency of the mill. This means that there is no easy way to pick the type of mills where BECCS should be first promoted.

\subsection{Role of auxiliary fossil fuel type}

The effect of fossil fuel price and the choice of fossil fuel was estimated by varying the fossil fuel prices in Cases A, B, and C, and then calculating the difference caused by the fuel choice for each mill. The specific fossil fuel consumption varies between mills (Fig. 2), and they use either natural gas or heavy fuel oil (Table 1). The energy production from fossil fuels was kept constant, and fossil $\mathrm{CO}_{2}$ production was calculated for each mill for both $\mathrm{NG}$ and HFO. The difference in production costs was then calculated based on the ETS prices and the varying fossil fuel prices. As combustion of $\mathrm{HFO}$ produces more $\mathrm{CO}_{2}$ emissions per generated energy than combustion of $\mathrm{NG}$, it can be concluded that the combination of increased ETS price and HFO price increase in relation to NG price notably increases production costs. The price variation in the calculations was thus limited to HFO price decrease and NG price increase. Figure 7 presents the results as the difference between NG use and HFO use: the negative values indicate the cases where HFO use is the more costefficient option. The base case was calculated using oil price of $58 € / \mathrm{MWh}$, and natural gas price of $48 € / \mathrm{MWh}$, which was the price level in Finland at the end of 2019 (Statistics Finland, 2019). The figure highlights the expensiveness of oil use in relation NG use. The results show that, fuel prices being at the abovementioned level, natural gas is the more feasible option for all mills, and it would require a notable increase in natural gas price or low oil or ETS prices to make oil use more economical. This can be seen, especially in Case $\mathrm{C}$, where NG is the cheaper option even when its price raises and oil price decreases significantly.

\section{Discussion}

The pulp industry can take a notable role in $\mathrm{CO}_{2}$ emission reduction due to its significant fossil $\mathrm{CO}_{2}$ emission production and as it is a large user of energy, especially bioenergy. Therefore, it is essential to discuss how this sector can answer to the increasing demand for emission reduction. The possible pathways for emission reduction as well as the reduction potential should interest both policymakers and industrial operators. Recent scenarios on the Finnish pulp and paper industry (Lipiäinen and Vakkilainen, 2021) show that nearly carbon-neutral production can be achieved by the year 2035. Totally carbon-neutral or carbon-negative production requires negative emissions, e.g., in the form of BECCS. This indicates that the pulp and paper sector can contribute to the climate change mitigation via 
Fig. 7 Difference in production cost $\left(€ / t_{\text {product }}\right)$ between the choice of natural gas $(\mathrm{NG})$ or heavy fuel oil $\downarrow$ (HFO) use when the prices of fuels vary in Cases A a, B b, and C c. Positive values indicate that natural gas is more economical option and negative values state that oil use is cheaper

changes in energy use and production, which is important for a large, energy-intensive sector. In the pulp and paper sector, energy is not only a commodity but also a part of the production processes. Energy efficiency is not only a climate issue, but also a significant cost factor in pulp and paper production. Many industrial operators are therefore continuously looking for solutions for its improvement, regardless of the demand for cleaner production. For efficient reduction in emissions, solutions like CCS and BECCS are highly essential for energy-intensive industries.

Even though BECCS deployment in pulp and paper mills is not a sole solution for the climate change, it can be a significant contributor in diminishing the amount of $\mathrm{CO}_{2}$ in the atmosphere. Unit size is a significant factor in CCS costs (Garðarsdóttir et al., 2018), and thus, the large pulping units offer an attractive possibility to capture $\mathrm{CO}_{2}$ from large point sources. The pulp industry has also been in the frontline in developing new processes toward higher sustainability. This is in line with the recent global efforts to reduce dependence on both fossil fuels and fossil-based products. The objective to make the traditional pulp and paper processes more sustainable is even more justified as the pulp industry is continuously developing novel bioeconomy solutions, such as pulp-based substitutes for fossil products. Although the demand for some paper products has been decreasing lately, for example sustainable packaging material production is on the rise. The coming decades will show how the advanced wood-based products will be received in the markets. The future of the pulp and paper industry depends on the success of the new production pathways, but also on the willingness of policymakers to create policy instruments to promote this development, e.g., by supporting negative emissions from pulp mills.

The development of the emission trading and forthcoming demand on emission reduction are likely to affect the market prices of pulp and paper products in the EU. As the results of this study show, an ETS price of $75 € / t_{\mathrm{CO} 2}$ can increase the production costs of pulp and paper up to $24 € / t_{\text {product }}$, even when allocated only to fossil $\mathrm{CO}_{2}$. It should also be noticed that this study only considered the direct costs from ETS. The mills that purchase electricity or heat are also affected by possible price increase in the purchased energy due to ETS. When BECCS is applied, a negative emission compensation could cover the costs of it or, in the best case, even decrease production costs. Market kraft pulp mills followed by testliner mills have the lowest shares of fossil $\mathrm{CO}_{2}$ emissions and are the most promising mill groups for BECCS implementation. An $80 € / \mathrm{t}_{\mathrm{CO} 2}$ negative emission credit would lower market kraft pulp production costs by $10-19 € / \mathrm{t}_{\text {product }}$, when carbon capture rate is $50 \%$. The pulp prices were high during the year 2018, but decreased in 2019. The development in the beginning of 2021 showed again an increase (Maidell et al., 2021). Despite the decrease, prices have been relatively high considering the levels of the last decade. Climate actions and political decision-making are likely to affect the production costs of pulp and paper in the coming years; one of the key questions is the status of BECCS. The results of this study showed that the actual attractiveness of a BECCS investment depends not only on the possible negative emission compensation but also on other details related to the mill and company, such as the share of biogenic $\mathrm{CO}_{2}$ of all emissions. Although it can be concluded that some mill types on average are more likely to benefit from BECCS, it is challenging to pick the mills where BECCS should be first promoted, as its feasibility 
(a)

Case A: ETS price $25 € / \mathrm{t}_{\mathrm{CO} 2}$

25

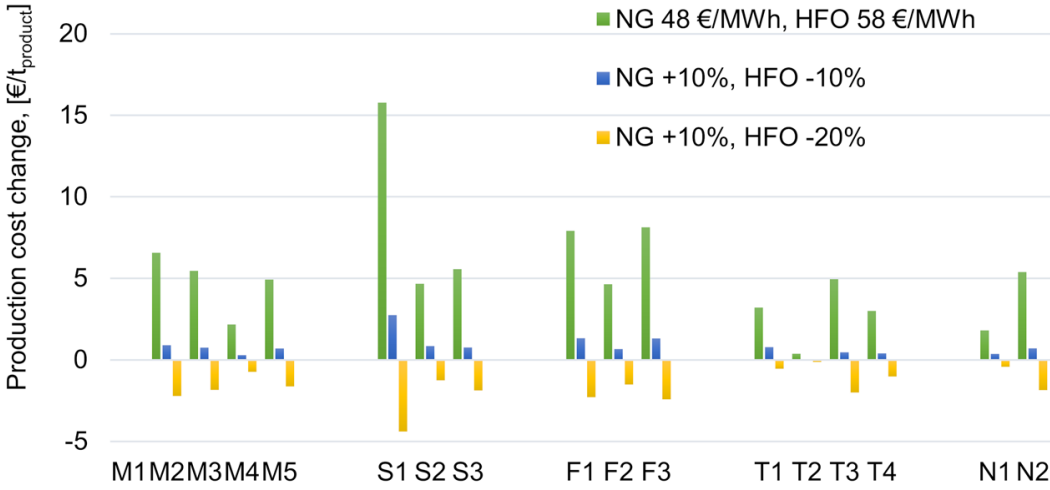

(b)

25

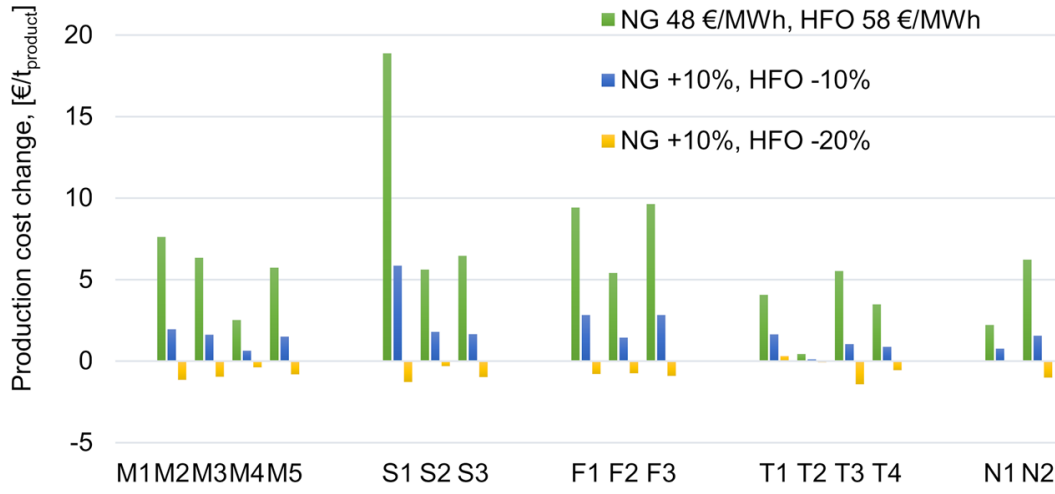

(C)

Case C: ETS price $75 € / \mathrm{t}_{\mathrm{CO} 2}$

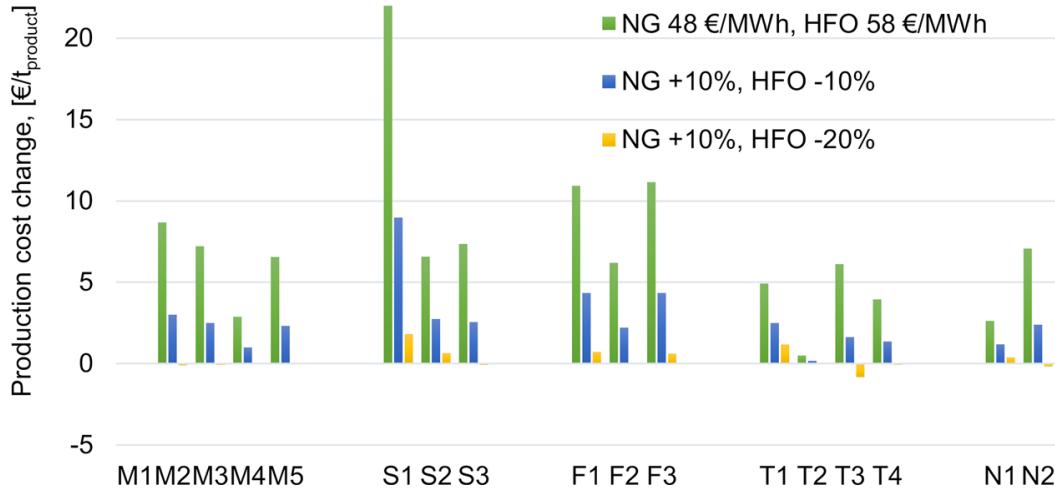


does not clearly correlate with the performance, technical age, nor the measured efficiency of the mill.

The results of this study do not assume or make suggestions on the probability to invest in BECCS in the case of an individual mill, but are merely designed to discuss the effect of such process integration on the production costs. The actual investment decisions depend on company details, i.e., capital resources, other investment needs, and willingness or need to apply new processes for strategic reasons. The results, however, show that many mills, especially market kraft pulp mills, can find BECCS implementation attractive given that negative emissions will be credited in the future.

\section{Conclusions}

The pulp and paper sector is a significant generator of energy from biomass, and therefore, the future utilization of BECCS can be considered an important measure for $\mathrm{CO}_{2}$ reduction in the sector. BECCS applications in the existing large pulp and paper units offer the possibility for BECCS implementation without additional biomass harvesting. Despite the relatively low share of fossil fuel use in the sector, purchase of emission allowances based on the total amount of produced fossil $\mathrm{CO}_{2}$ would increase notably the production costs of pulp and paper grades, depending on the mill, ETS price level, and choice of product. In particular, the production costs of magazine papers (SC/LWC) and fine papers would see significant increases with higher ETS price, as a price of $75 € / \mathrm{t}_{\mathrm{CO} 2}$ could increase the production costs of the first by $6-24 € / t_{\text {product }}$, and the latter by $6-16 € / t_{\text {product }}$.

Many mills have the possibility to act as a carbon sink with a relatively small carbon capture plant. Lower than $6 \% \mathrm{CO}_{2}$ capture rate would make all the studied market kraft pulp mills carbon-negative. Several carbon capture technologies exist, and it has been found technically feasible to integrate a capture process with the production of pulp and/or paper. The economic feasibility would require a negative emissions credit or other source of income from the biogenic $\mathrm{CO}_{2}$ to cover the capture costs. The pulp and paper industry is a diverse industrial sector, and the required level of credit depends greatly on the mill type and details. The least fossil $\mathrm{CO}_{2}$-intensive mill group, market kraft pulp mills, would find BECCS profitable with a credit in the range of $62-70 € / t_{\mathrm{CO} 2}$ when the capture rate is $50 \%$ of the total emissions of the mill. With a credit of $80 € / \mathrm{t}_{\mathrm{CO} 2}$, an average market kraft pulp mill would be able to lower pulp production costs by $2 € / t_{\text {product }}$ when $20 \%$ of $\mathrm{CO}_{2}$ is captured, and $15 € / \mathrm{t}_{\text {product }}$ when the capture rate is $50 \%$. On the other hand, in some magazine paper mills more than $50 \%$ of the emissions are fossil. These mills are not likely to find carbon capture feasible unless the ETS price exceeds the capture costs, which, based on recent estimates, are in the range of $40-92 € / t_{\mathrm{CO} 2}$. Based on the results of this study, the feasibility of BECCS does not correspond with the economic performance nor the energy efficiency level of the mills. Among the primary factors in the feasibility of carbon capture are $\mathrm{CO}_{2}$ intensity, the shares of fossil and biogenic emissions, and heat integration possibilities. Currently, BECCS is seen as an additional cost factor without offering a possibility for added income as no incentives for negative emissions exist within the current emission trade framework.

Author contributions All authors contributed to the study conception and design. Material preparation, data collection, and analysis were performed by KK, SL, and EV. The first draft of the manuscript was written by 
KK, and all authors commented on previous versions of the manuscript. All authors read and approved the final manuscript.

Funding Open Access funding provided by LUT University (previously Lappeenranta University of Technology (LUT)). The authors gratefully acknowledge the funding from the Academy of Finland for the project "Role of forest industry transformation in energy efficiency improvement and reducing $\mathrm{CO}_{2}$ emissions" Grant number 315019.

Data availability The study is based on publicly available data and material.

\section{Declarations}

Conflict of interest The authors have no conflicts of interest to declare that are relevant to the content of this article.

Open Access This article is licensed under a Creative Commons Attribution 4.0 International License, which permits use, sharing, adaptation, distribution and reproduction in any medium or format, as long as you give appropriate credit to the original author(s) and the source, provide a link to the Creative Commons licence, and indicate if changes were made. The images or other third party material in this article are included in the article's Creative Commons licence, unless indicated otherwise in a credit line to the material. If material is not included in the article's Creative Commons licence and your intended use is not permitted by statutory regulation or exceeds the permitted use, you will need to obtain permission directly from the copyright holder. To view a copy of this licence, visit http://creativecommons.org/licenses/by/4.0/.

\section{References}

Alakangas, E., Hurskainen, M., Laatikainen-Luntama, J., \& Korhonen, J. (2016). Suomessa käytettävien polttoaineiden ominaisuuksia (Properties of fuels used in Finland). (In Finnish). VTT Technical Research Centre of Finland, Espoo, Finland.

European Commission. (2018). In-depth analysis in support of the COM(2018) 773: A clean planet for all - A European long-term strategic vision for a prosperous, modern, competitive and climate neutral economy. European Commission, Brussels, Belgium.

European Commission. (2019a). Communication from the commission - The European Green Deal (COM(2019) 640 final). European Commission, Brussels, Belgium.

Energy Authority of Finland. (2019). Publications of the emissions trading. (In Finnish). Retrieved February 11, 2020, from https://energiavirasto.fi/en/publications-of-the-emissions-trading

European Commission. (2019b). Guidance Document $n^{\circ} 2$ on the harmonized free allocation methodology for the EU ETS post 2020 - Guidance on determining the allocation at installation level. European Commission, Directorate General Climate Action. Retrieved February 36, 2020, from https:// ec.europa.eu/clima/policies/ets/allowances_en\#tab-0

Finnish Forest Industries Federation. (2020). Statistics. Retrieved February 11, 2020, from https://www. forestindustries.fi/statistics/

Fleiter, T., Fehrenbach, D., Worrell, E., \& Eichhammer, W. (2012). Energy efficiency in the German pulp and paper industry - A model-based assessment of saving potentials. Energy, 40(1), 84-99. https://doi.org/10.1016/j.energy.2012.02.025

Fridahl, M., \& Lehtveer, M. (2018). Bioenergy with carbon capture and storage (BECCS): Global potential, investment preferences, and deployment barriers. Energy Research \&amp; Social Science, 42, 155-165. https://doi.org/10.1016/j.erss.2018.03.019

Fuss, S., Lamb, W., Callaghan, M., Hilaire, J., Creutzig, F., Amann, T., Beringer, T., de Oliveira Garcia, W., Hartmann, J., Khanna, T., Luderer, G., Nemet, G., Rogelj, J., Smith, P., Vicente Vicente, J., Wilcox, J., Dominguez, M., \& Minx, J. (2018). Negative emissions - Part 2: Costs, potentials and side effects. Environmental Research Letters, 13, 063002. https://doi.org/10.1088/1748-9326/aabf9f

Garðarsdóttir, S., Normann, F., Skagestad, R., \& Johnsson, F. (2018). Investment costs and $\mathrm{CO}_{2}$ reduction potential of carbon capture from industrial plants - A Swedish case study. Int. J. Greenh. Gas Control, 76, 111-124. https://doi.org/10.1016/j.ijggc.2018.06.022

Hansson, A., Fridahl, M., Haikola, S., Yanda, P., Pauline, N., \& Mabhuye, E. (2020). Preconditions for bioenergy with carbon capture and storage (BECCS) in sub-Saharan Africa: The case of 
Tanzania. Environment, Development and Sustainability, 22, 6851-6875. https://doi.org/10.1007/ s10668-019-00517-y

IEAGHG. (2016). Techno-economic evaluation of retrofitting CCS in a market pulp mill and an integrated pulp and board mill. IEA Greenhouse Gas R\&D Programme, Cheltenham, UK.

IndexMundi. (2021). Commodity prices. Retrieved April 6, 2021, from https://www.indexmundi.com/ commodities/

International Energy Agency (IEA). (2019). Tracking Industry. Retrieved February 13, 2020, from https://www.iea.org/reports/tracking-industry

International Energy Agency (IEA). (2020). Special report on carbon capture, utilisation and storage: CCUS in clean energy transitions. International Energy Agency, Paris, France.

IRENA. (2018). Bioenergy from Finnish forests: Sustainable, efficient and modern use of wood. International Renewable Energy Agency (IRENA). Retrieved January 16, 2020, from https://www.irena. org/-/media/Files/IRENA/Agency/Publication/2018/Mar/IRENA_Bioenergy_from_Finnish_fores ts_2018.pdf

Jönsson, J., \& Berntsson, T. (2012). Analysing the potential for implementation of CCS within the European pulp and paper industry. Energy, 44, 641-648. https://doi.org/10.1016/j.energy.2012.05.028

Kähkönen, S., Vakkilainen, E., \& Laukkanen, T. (2019). Impact of structural changes on energy efficiency of finnish pulp and paper industry. Energies, 12(19), 3689. https://doi.org/10.3390/en121 93689

Karjunen, H., Tynjälä, T., \& Hyppänen, T. (2017). A method for assessing infrastructure for $\mathrm{CO}_{2}$ utilization: A case study of Finland. Applied Energy, 205, 33-43. https://doi.org/10.1016/j.apenergy.2017. 07.111

Kearns, D., Liu, H. \& Consoli, C. (2021). Technology readiness and costs of CCS. Global CCS Institute, Brussels, Belgium.

Kuparinen, K., \& Vakkilainen, E. (2017). Green pulp mill: Renewable alternatives to fossil fuels in lime kiln operations. BioResources, 12(2), 4031-4048. https://doi.org/10.15376/biores.12.2.4031-4048

Kuparinen, K., Vakkilainen, E., \& Tynjälä, T. (2019). Biomass-based carbon capture and utilization in kraft pulp mills. Mitigation and Adaptation Strategies for Global Change, 24, 1213-1230. https:// doi.org/10.1007/s11027-018-9833-9

Leeson, D., Mac Dowell, N., Shah, N., Petit, C., \& Fennell, P. (2017). A techno-economic analysis and systematic review of carbon capture and storage (CCS) applied to the iron and steel, cement, oil refining and pulp and paper industries, as well as other high purity sources. Int. J. Greenh. Gas Control, 61, 71-84. https://doi.org/10.1016/j.ijggc.2017.03.020

Lipiäinen, S., \& Vakkilainen, E. (2021). Role of Finnish forest industry in mitigating global change: Energy use and greenhouse gas emissions towards 2035. Mitigation and Adaptation Strategies for Global Change, 26, 1-19. https://doi.org/10.1007/s11027-021-09946-5

Maidell, M., Valonen, M., Horne, P., \& Sajeva, M. (2021). PTT:n metsäalan ennuste: Kevät 2021 (PTT's Forest industry forecast: Spring 2021). (In Finnish). Pellervo Economic Research PTT. Retrieved May 12, 2021, from https://www.ptt.fi/media/ennusteet/metsa/2021/metsaalan-ennuste-paivityskevat2021.pdf

Moya, J., \& Pavel, C. (2018). Energy efficiency and GHG emissions: Prospective scenarios for the pulp and paper industry. Publications Office of the European Union. https://doi.org/10.2760/035301

Onarheim, K., Garðarsdòttir, S., Mathisen, A., Nord, L. \& Berstad, D. (eds). (2015b) Industrial implementation of carbon capture in Nordic industry sectors. Nordic CCS Competence Centre, NORDICCS. Retrieved August 11, 2021, from https://www.sintef.no/globalassets/sintef-energi/nordiccs/ d4.2.1501-d18-co2-capture-cases.pdf

Onarheim, K., Mathisen, A., \& Arasto, A. (2015). Barriers and opportunities for application of CCS in Nordic industry - A sectorial approach. Int. J. Greenh. Gas Control, 36, 93-105. https://doi.org/10. 1016/j.ijggc.2015.02.009

Onarheim, K., Santos, S., Kangas, P., \& Hankalin, V. (2017a). Performance and costs of CCS in the pulp and paper industry part 1: Performance of amine-based post-combustion $\mathrm{CO}_{2}$ capture. Int. J. Greenh. Gas Control, 59, 58-73. https://doi.org/10.1016/j.ijggc.2017.02.008

Onarheim, K., Santos, S., Kangas, P., \& Hankalin, V. (2017b). Performance and cost of CCS in the pulp and paper industry Part 2: Economic feasibility of amine-based post-combustion $\mathrm{CO}_{2}$ capture. International Journal of Greenhouse Gas Control, 66, 60-75. https://doi.org/10.1016/j.ijggc.2017. 09.010

Statistics Finland. (2019). Energy prices 3rd Quarter 2019. Retrieved May 17, 2020, from https://tilas tokeskus.fi/til/ehi/2019/03/ehi_2019_03_2019-12-11_tie_001_en.html

Statistics Finland. (2020). Fuel classification 2020. Retrieved February 11, 2020, from https://www.stat. fi/tup/khkinv/khkaasut_polttoaineluokitus.html 
Stenqvist, C., \& Åhman, M. (2016). Free allocation in the 3rd EU ETS period: Assessing two manufacturing sectors. Climate Policy, 16(2), 125-144. https://doi.org/10.1080/14693062.2014.979130

Teir, S., Hetland, J., Lindeberg, E., Torvanger, A., Buhr, K., Koljonen, T., Gode, J., Onarheim, K., Tjernshaugen, A., Arasto, A., Liljeberg, M., Lehtilä, A., Kujanpää, L. \& Nieminen, M. (2010). Potential for carbon capture and storage (CCS) in the Nordic region. VTT Technical Research Centre of Finland, Espoo, Finland.

Vakkilainen, E., Kuparinen, K. \& Heinimö, J. (2013). Large industrial users of energy biomass. IEA Bioenergy Task 40. Retrieved January 13, 2020, from https://www.ieabioenergy.com/publications/ large-industrial-users-of-energy-biomass/

Vakkilainen, E., \& Kivistö, A. (2014). Forest industry energy consumption - trends and effects of modern mills. Lappeenranta University of Technology.

Publisher's Note Springer Nature remains neutral with regard to jurisdictional claims in published maps and institutional affiliations. 